


\section{Welke drankverpakkingen zouden beter gerecycled kunnen worden wanneer ze ook via een statiegeldsysteem zouden worden ingezameld?}

Auteurs: E.U. Thoden van Velzen, M.T. Brouwer

Instituut: Wageningen Food and Biobased Research

Dit onderzoek is uitgevoerd door Wageningen Food \& Biobased Research, gefinancierd door en in opdracht van Ministerie van Infrastructuur en Waterstaat. 
WFBR Project nummer: 6229087100

Versie: Definitief

Reviewer: I.W. Smeding

Goedgekeurd door: A. van der Bent

Gefinancierd door: Ministerie van Infrastructuur en Waterstaat

In opdracht van: Ministerie van Infrastructuur en Waterstaat

Vertrouwelijkheid van het rapport: Openbaar

Dit rapport is gratis te downloaden op https://doi.org/10.18174/549191 of op www.wur.nl/wfbr (onder publicaties).

Rechten foto voorpagina: ValeStock / Shutterstock.com

(C) 2021 Wageningen Food \& Biobased Research, instituut binnen de rechtspersoon Stichting Wageningen Research.

Het is de opdrachtgever toegestaan dit rapport integraal openbaar te maken en ter inzage te geven aan derden. Zonder voorafgaande schriftelijke toestemming van Wageningen Food \& Biobased Research is het niet toegestaan:

a. dit door Wageningen Food \& Biobased Research uitgebrachte rapport gedeeltelijk te publiceren of op andere wijze gedeeltelijk openbaar te maken;

b. dit door Wageningen Food \& Biobased Research uitgebrachte rapport, c.q. de naam van het rapport of Wageningen Food \& Biobased Research, geheel of gedeeltelijk te doen gebruiken ten behoeve van het instellen van claims, voor het voeren van gerechtelijke procedures, voor reclame of antireclame en ten behoeve van werving in meer algemene zin;

c. de naam van Wageningen Food \& Biobased Research te gebruiken in andere zin dan als auteur van dit rapport.

Postbus 17, 6700 AA Wageningen, T 03174800 84, E info.wfbr@wur.nl, www.wur.nl/wfbr. Wageningen Food \& Biobased Research is onderdeel van Wageningen University \& Research.

Alle rechten voorbehouden. Niets uit deze uitgave mag worden verveelvoudigd, opgeslagen in een geautomatiseerd gegevensbestand of openbaar gemaakt in enige vorm of op enige wijze, hetzij elektronisch, hetzij mechanisch, door fotokopieën, opnamen of enige andere manier, zonder voorafgaande schriftelijke toestemming van de uitgever. De uitgever aanvaardt geen aansprakelijkheid voor eventuele fouten of onvolkomenheden. 


\section{Inhoud}

$1 \quad$ Inleiding $\quad 4$

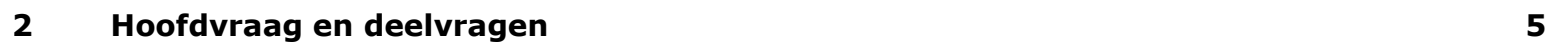

3 Welke drankverpakkingen vallen nu binnen en buiten het statiegeldsysteem? 6

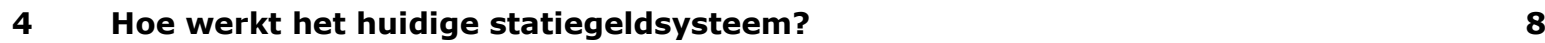

5 Welke voorwaarden worden aan drankverpakkingen gesteld om ze efficiënt in te zamelen via het statiegeldsysteem?

6 Waarom functioneert het huidige statiegeldsysteem zo goed?

7 Welke gevolgen heeft een uitbreiding van het statiegeldsysteem?

7.1 Gevolgen voor eigenaren van inzamelpunten 11

\begin{tabular}{ll}
7.2 & Gevolgen voor burgers \\
\hline
\end{tabular}

7.3 Gevolgen voor de kwaliteit van de ingezamelde verpakkingen 12

8 Wat zijn de verwachte effecten per categorie drankverpakkingen die aanvullend toegevoegd zouden kunnen worden?

$9 \quad$ Algemene noot ter afsluiting 


\section{Inleiding}

Naar aanleiding van de Motie Beckerman van 20 april 2021 is Wageningen Food en Biobased Research (WFBR) benaderd door het Ministerie van IenW met de volgende vraag: "Welke drankverpakkingen zouden beter gerecycled kunnen worden wanneer ze ook via een statiegeldsysteem zouden worden ingezameld?". WFBR en het Ministerie zijn overeengekomen deze vraag beknopt te beantwoorden op basis van bij de onderzoekers aanwezige kennis. Er heeft dus geen uitgebreid onderzoek

plaatsgevonden, maar dit document is opgesteld op basis van beschikbare kennis over het onderwerp. Opdrachtverlening verliep middels een "flitsopdracht". 


\section{Hoofdvraag en deelvragen}

De hoofdvraag die beantwoord wordt in dit document luidt: "Welke drankverpakkingen zouden beter gerecycled kunnen worden wanneer ze ook via een statiegeldsysteem zouden worden ingezameld?"

Deze hoofdvraag zullen we beantwoorden aan de hand van de volgende deelvragen:

- Welke drankverpakkingen vallen nu binnen en buiten het statiegeldsysteem?

- Hoe werkt het huidige statiegeldsysteem?

- Welke voorwaarden worden aan drankverpakkingen gesteld om ze efficiënt in te zamelen via het statiegeldsysteem?

- Waarom functioneert het huidige statiegeldsysteem zo goed?

- Welke gevolgen heeft een uitbreiding van het statiegeldsysteem?

- Wat zijn de verwachte effecten per categorie drankverpakkingen die aanvullend toegevoegd zouden kunnen worden? 


\section{Welke drankverpakkingen vallen nu binnen en buiten het statiegeldsysteem?}

Op dit moment (juni 2021) worden in Nederland de volgende drankverpakkingen ingezameld met een statiegeldsysteem:

- Kunststof flessen voor water en frisdrank met een inhoud van meer dan een halve liter (dit zijn nu uitsluitend PET flessen),

- Het grootste deel van de bierflessen (de bruine Nederlandse retourflessen, merkflessen en de meeste importflessen nemen deel aan het statiegeldsysteem),

- Aanvullend gebruiken lokale boerenwinkels hervulbare glazen flessen voor zuivelproducten.

Vanaf 1 juli 2021 worden hieraan de PET flessen voor water en frisdrank, met een inhoudsmaat van een halve liter en minder, toegevoegd. Vanaf 1 januari 2023 worden hier ook drankblikjes aan toegevoegd. Drankblikjes zijn momenteel voor het grootste deel gemaakt van aluminium en voor een klein deel van dunstaal.

Dat betekent dat vanaf 2023 de volgende drankverpakkingen buiten het statiegeldsysteem vallen:

- PET flessen voor diverse sap- en zuivelproducten (vruchtensappen, melk, drinkyoghurt, chocolademelk, ijskoffie, etc.),

- PET flessen voor wijn, bier en andere alcoholische dranken,

- HDPE drankflessen, dit is een relatief grote categorie met min of meer blokvormige melk- en sapcontainers of jugs met een inhoudsmaat van vaak anderhalve liter of meer. Daarnaast zijn er ook HDPE flessen voor gesteriliseerde melk en melkproducten en kleine HDPE flesjes voor probiotische dranken.

- PP en PS drankflessen. PP drankflessen worden gebruikt voor fruitsappen en PS drankflessen voor probiotische dranken.

- Glazen drankflessen anders dan de bierflessen die nu wel onderdeel maken van het statiegeldsysteem, denk hierbij aan glazen flessen met wijn, sterke dranken, sap, frisdranken, zuivel en bierflessen van enkele importmerken en kleine brouwers .

- Drankenkartons, veelal in gebruik voor sap en zuivel.

- Afwijkende drankverpakkingen als stazakjes, ook wel pouches genaamd, denk hierbij aan CapriSun en Breaker.

De marktomvang van deze drankflessen op de Nederlandse markt werd ingeschat op basis van vertrouwelijke inzichten van producenten, incomplete marktgegevens en analyses van het Nederlandse restafval en het PMD materiaal [Brouwer et al., 2018, 2019 en 2021; Thoden van Velzen et al., 2017]. Omdat soms de schattingen licht van elkaar verschilden en soms ook moesten worden afgeschat vanuit een deelverzameling van een groter aandeel, worden de schattingen met marges gepresenteerd. De schattingen staan in tabel 1 
Tabel 1 Schattingen van de marktomvang van drankverpakkingen op de Nederlandse markt in kiloton netto per jaar.

\begin{tabular}{lc} 
Soort drankverpakking & Geschatte marktomvang, [kton/jaar] \\
Grote PET flessen voor water en frisdrank binnen & $20-25$ \\
statiegeldsysteem & \\
\hline Bierflessen binnen statiegeldsysteem & $450-460$ \\
\hline Kleine PET flesjes voor water en frisdrank die in juli 2021 & $10-12$ \\
worden toegevoegd aan statiegeldsysteem & $15-18$ \\
Drankbussen die in 2023 worden toegevoegd aan & \\
statiegeldsysteem & $2-3$ \\
\hline PET flessen voor sap en zuivel & $<1$ \\
\hline PET flesjes voor wijn en bier & $1-3$ \\
\hline HDPE melkcontainers & $0.5-1.0$ \\
\hline HDPE sap-containers & $0.5-1.0$ \\
\hline Andere HDPE flessen & $<1$ \\
\hline PS drankflessen & $<1$ \\
\hline PP drankflessen & $13-17$ \\
\hline Glazen drankflessen (alleen consumentverpakkingen) & $190-210$ \\
\hline Glazen flessen voor wijn, gedestilleerd en sterke drank & $35-40$
\end{tabular}




\section{Hoe werkt het huidige statiegeldsysteem?}

Bij de aankoop van een fles met drank in een Nederlandse winkel, brengt de verkoper statiegeld in rekening als de fles tot het statiegeldsysteem hoort. Dit bedraagt in Nederland 25 Eurocent voor een grote PET fles, 10 Eurocent voor een bierfles en $€ 1,50$ voor een standaard bierkrat. Na gebruik levert de burger zijn drankverpakkingen weer in bij een verkooppunt. Bij supermarkten zijn hiervoor doorgaans retourname machines. Hier worden losse flessen via de ronde opening aan de bovenzijde één voor één ingevoerd met de bodem eerst. De kratten worden onderin ingevoerd. De flessen worden optisch gecontroleerd op de aanwezigheid van een EAN code (streepjescode) en op vorm. Komt de EAN code overeen met flessen in het Nederlandse statiegeldsysteem dan gaat de fles door, anders wordt de fles geweigerd. Vervolgens vindt er nog een controle plaats van het gewicht van de geretourneerde fles. Als het gewicht redelijk overeenkomt gaat de fles door, als het gewicht niet overeenkomt wordt deze geweigerd. De goede flessen worden verzameld in grote plastic zakken die door de winkeleigenaar worden afgesloten met een zegel. Bierflessen die via de ronde opening naar binnen komen lopen door naar de sorteertafel. Daar worden ze door een medewerk(st)er van de supermarkt in het goede krat gezet. De kratten komen onderlangs naar binnen. De kratten worden optisch gecontroleerd op EAN code, vorm en het aantal flesjes dat er in aanwezig is. Ook wordt optisch gecontroleerd of de juiste soort flesjes in het krat zitten. Wanneer er andere flessen in het krat aanwezig zijn, wordt de krat geweigerd en moeten de afwijkende flessen eerst worden verwijderd en apart door de ronde opening worden ingevoerd. Goedgekeurde kratten worden door winkelpersoneel zo nodig nog gevuld met los retour-komende bierflesjes van hetzelfde soort.

De zakken met PET flessen en de kratten met lege bierflesjes gaan terug naar de distributiecentra van de supermarkten. Supermarkten die aangesloten zijn bij SRN (Statiegeld Retourverpakkingen Nederland) sturen vervolgens de zakken met PET flessen naar één van de drie telcentra. Daar worden de verzegelde zakken geopend en de flessen één voor één gecontroleerd of ze wel of niet in het SRN systeem horen en op basis van de telling wordt de winkelier gecompenseerd. $\mathrm{Er}$ is een toegesneden financieel vergoedingssysteem zodat individuele winkeliers precies terugkrijgen waar ze recht op hebben. De telcentra zorgen ervoor dat er balen met statiegeldflessen naar recyclingbedrijven worden gestuurd, waar de flessen worden gemalen, gewassen en geëxtrudeerd tot nieuwe PET pellets. Deze worden verhandeld aan bedrijven die hieruit weer nieuwe preforms spuitgieten, waarbij vervolgens nieuwe flessen worden geblazen. Zo kan het materiaal uit de eenmalige PET flessen weer gebruikt worden voor de productie van nieuwe flessen. Bierflessen en kratten zijn daarentegen meermalig bruikbaar. Ze worden vanuit de distributiecentra direct naar de brouwers teruggestuurd. Daar worden de flessen uit de krat genomen, intensief gewassen en optisch gecontroleerd op mogelijke defecten en dan weer ingezet om bier af te vullen. Ook de kratten worden apart gewassen en weer hergebruikt . 


\section{Welke voorwaarden worden aan drankverpakkingen gesteld om ze efficiënt in te zamelen via het statiegeldsysteem?}

Een drankverpakking kan efficiënt via het statiegeldsysteem worden ingezameld als:

- De verpakking niet vervormt na gebruik en de streepjescode goed te lezen is,

- De vorm van de drankverpakking past door de opening van de retourmachine,

- De verpakking is liefst hersluitbaar, zodat productresten zo min mogelijk uit de verpakking komen en de machine en de sorteertafels niet vervuild raken, (dit is overigens niet het geval bij bierflesjes en blikjes en is daarmee ook een bezwaar van de eigenaren van de inzamelpunten tegen het op deze wijze inzamelen van deze drankverpakkingen).

- Er moeten zo min mogelijk productresten in de verpakking achterblijven, zodat de inzamelmachine en het supermarktmagazijn niet vervuilt. Dit is vooral voor viskeuze dranken (zoals bijvoorbeeld drinkyoghurt) een uitdaging. 


\section{Waarom functioneert het huidige statiegeldsysteem zo goed?}

In juni 2021 zijn er drie statiegeldsystemen actief in Nederland: Stichting Retourverpakking Nederland (SRN), Aldi en Lidl. Hiervan is SRN verreweg het grootste en hiervan is ook de meeste informatie beschikbaar. Dit statiegeldsysteem functioneert zo goed omdat:

- $\quad$ Er een financiële prikkel is om de flessen te retourneren,

- De verpakkingen zijn goed herkenbaar voor burgers als statiegeldflessen,

- De bierflessen zijn gestandaardiseerd als BNR (Bruine Nederlandse Retourfles), merkflessen en een beperkt aantal modellen importflessen,

- Alle grote PET flessen zijn ontworpen voor recycling,

- $\quad$ Er zijn geen productresten in de flessen aanwezig die lastig te verwijderen zijn.

Doordat de PET flessen ontworpen zijn voor recycling, kan er ook een goede kwaliteit gerecycled PET uit worden gemaakt met relatief geringe procesverliezen ten opzichte van het gerecycled PET dat gemaakt wordt uit andere inzamelsystemen (waar de flessen nog niet allemaal ontworpen zijn voor recycling en soms ook verstorende productresten bevatten). Bovendien is de vervuiling van het buitenoppervlak van de flessen in het statiegeldsysteem gering en verwaarloosbaar ten opzichte van vergelijkbare flessen in het PMD en nascheiding-systeem. 


\section{Welke gevolgen heeft een uitbreiding van het statiegeldsysteem?}

$\mathrm{Er}$ is brede consensus dat de retourpercentages van statiegeldsystemen hoger liggen dan van de meeste gescheiden inzamelsystemen, mits het statiegeldsysteem goed wordt uitgevoerd. Dus als de borg voldoende hoog is, dat er een hoog serviceniveau wordt gehanteerd (voldoende inzamelpunten die goed te bereiken zijn en met geringe wachttijden) en dat er geen concurrerende inzamelmogelijkheden zijn die evenveel gemak bieden [Zhou et al, 2020; Picuno et al., 2021]. Dus het eerste, meest in het oog springende, gevolg van een uitbreiding van het statiegeldsysteem is dat het retourpercentage voor de onderhavige verpakkingen stijgt.

Maar een uitbreiding heeft ook gevolgen die minder duidelijk zichtbaar zijn. Dit betreft gevolgen voor de eigenaren van inzamelpunten en burgers die flessen retour brengen en voor de kwaliteit van de ingezamelde verpakkingen.

\subsection{Gevolgen voor eigenaren van inzamelpunten}

Een vaak onderschat aspect is het grote volume van de statiegeldflessen. De bierflessen moeten gesorteerd worden op sorteertafels, worden in kratten verzameld en gaan retour. Deze kratten worden gestapeld en nemen een fors volume in beslag. De lege PET flessen worden centraal in telcentra geteld en mogen daarom niet geplet worden. Zodoende worden de lege PET flessen verzameld in grote, lichte zakken en opgeslagen in het magazijn van het inzamelpunt totdat er retourtransport is. Hiervoor moet elk inzamelpunt (vaak een supermarkt) een forse ruimte in zijn magazijn reserveren. De huidige ervaring is dat de meeste flessen op vrijdag en zaterdag teruggebracht worden en dat de piek van het retourtransport op zaterdag, maandag en dinsdag ligt. Als het statiegeldsysteem uitgebreid wordt met aanvullende verpakkingen spelen er meerdere aspecten voor de eigenaren van de inzamelpunten. Ten eerste zijn er mogelijk nieuwe inzamelmachines nodig omdat de opening van de machine moet worden aangepast. Ten tweede zal er aanvullende ruimte nodig zijn voor het bufferen van de retour-gaande verpakkingen. Sommige inzamelpunten overwegen om retour komende kleine PET flesjes en blikjes apart te gaan compacteren om ruimte te besparen. Hierbij ontstaat een kleine hoeveelheid uitgeperste vloeibare productrest dat verantwoord moet worden afgevoerd zonder geurhinder te veroorzaken.

\subsection{Gevolgen voor burgers}

Voor burgers is de wachttijd bij de inzamelmachines nu nog te overzien. De wachttijden kunnen mogelijk gaan oplopen door de nu al afgekondigde uitbreidingen van het statiegeldsysteem (kleine PET flessen en blikjes). Om dit te voorkomen, is afgesproken dat het aantal inzamelpunten wordt uitgebreid. In het geval de overheid besluit de statiegeldplicht uit te breiden en dit onverhoopt toch gevolgen heeft voor wachttijden bij de retourmachines, kan dit leiden tot ergernis bij burgers en vertegenwoordigers van inzamelpunten. Aanvullend zullen de burgers in hun huis ruimte moeten vrij maken om deze verpakkingen tijdelijk op te slaan, en is het mogelijk niet altijd even duidelijk voor welke verpakkingen wel of geen statiegeldplicht is. 


\subsection{Gevolgen voor de kwaliteit van de ingezamelde verpakkingen}

Negatieve effecten op de kwaliteit van het gerecyclede materiaal (glas, PET, aluminium) zijn alleen te verwachten als de toegevoegde verpakkingen niet ontworpen zijn voor recycling (en daarmee contaminanten in het recyclaat introduceren) of als de verpakkingen productresten meenemen en daarmee de andere verpakkingen bevuilen. Of deze effecten optreden zal afhangen van hoe de telcentra en de recyclingbedrijven zullen omgaan met deze aanvullende stromen; bijvoorbeeld of men de grote en de kleine PET flessen apart gaat afvoeren en verwerken of juist gecombineerd.

Verder heeft het openen van een nieuwe inzamelwijze voor relatief waardevol verpakkingsafval negatieve gevolgen op de bestaande inzamelwijzen, immers het onttrekt grondstoffen voor hen. Dus bijvoorbeeld het onttrekken van potentieel goed recyclebare kunststofverpakkingen aan het PMD inzamelsysteem zal de kosten van het inzamelen en sorteren van PMD per gewichtseenheid verhogen. Daarbij worden dan juist deze goed recyclebare verpakkingen uit het PMD onttrokken en wanneer teveel van deze goed recyclebare verpakkingen uit het PMD worden onttrokken kan dat een negatief effect hebben op de kwaliteit van de gerecyclede kunststoffen die nog gemaakt kunnen worden uit de achterblijvende verpakkingen. Hier kan men het perspectief tegenover stellen dat dergelijk goed recyclebare verpakkingen niet thuis horen in een gecombineerde inzamelstroom als PMD. 


\section{Wat zijn de verwachte effecten per categorie drankverpakkingen die aanvullend toegevoegd zouden kunnen worden?}

Hierbij kijken we zowel naar de invloed op het inzamelsysteem zelf als de verwachte effecten op de kwaliteit van de teruggewonnen grondstoffen (bijvoorbeeld glasscherven en rPET granulaat), als het potentiële voordeel voor de toekomstige circulaire economie. In Tabel 2 is een overzicht van de voor en nadelen van het opnemen in een statiegeldsysteem van verschillende drankverpakkingen weergegeven.

1. PET flessen voor sap- en zuivelproducten. In deze categorie drankflessen worden voornamelijk sappen, drinkyoghurts, ijskoffie en chocolademelkproducten verkocht en nauwelijks gewone melk. De productresten in deze flessen koeken vaak aan. Daarnaast vormen er zich biologische afbraakproducten die sterk kunnen ruiken. De kans dat het recyclingproces niet alle aangekoekte resten en geurmoleculen kan verwijderen wordt groter naarmate er meer flessen met deze productresten aanwezig zijn. Dit geldt in mindere mate voor gewone melk, maar in sterke mate voor sappen met vruchtvlees en drinkyoghurts etc. Aanvullend zijn er sap-flessen op de Nederlandse markt die een zuurstof-absorberende tussenlaag of gas-barrière-laag hebben. Hiermee wordt de houdbaarheid van het sap verlengd en daarmee voedselverspilling beperkt. Tijdens recycling kleuren de PET snippers van deze flessen bruin, waardoor het rPET in zijn geheel geler kleurt en daarmee verdund moet worden om nog acceptabel te blijven voor hergebruik in transparante flessen. Dus het toevoegen van deze sap- en zuivelflessen zou de kwaliteit van het huidige rPET granulaat verlagen.

2. PET flessen voor wijn en bier. Een klein marktaandeel van wijn en bier wordt verpakt in PET flessen. Deze flessen hebben vaak een kleine inhoudsmaat, zijn vaak groen of bruin van kleur en bezitten vaak een barrière-laag of een zuurstof-absorber. Dit is noodzakelijk omdat deze producten heel gevoelig zijn voor oxidatie. Deze flessen kunnen nu niet hoogwaardig worden gerecycled. Daarom is er geen duidelijke meerwaarde om deze aan het statiegeldsysteem toe te voegen.

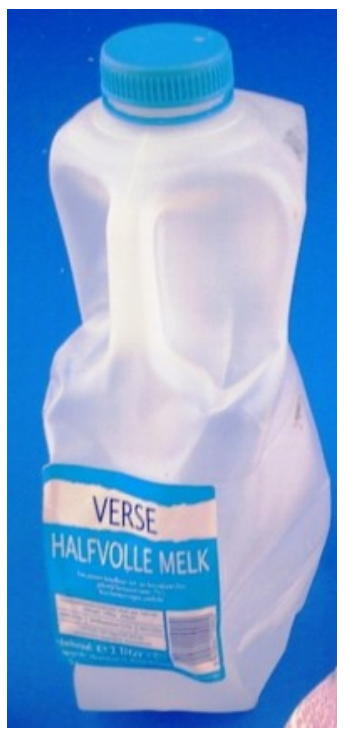

Figuur 1

Foto van een melkcontainer (ook wel jug genaamd) na gebruik.

3. HDPE melkcontainers (jugs), zie figuur 1. Het voornaamste nadeel aan deze verpakking is de vorm. Hij past niet door de ronde opening van het inzamelapparaat. Op zich past hij wel door 
de kratteninvoer, maar de huidige retourapparaten zijn hier voor niet geschikt. Aangezien inzamelpunten net hebben geïnvesteerd in nieuwe inzamelapparaten om ook kleine PET flessen en blikjes te gaan inzamelen, is dit onwenselijk vanuit oogpunt van de inzamelaar. Het potentiële voordeel is daarentegen groot. De gescheiden inzameling van deze verpakkingen betekent namelijk een concrete verbeterstap naar een meer circulaire economie. Immers deze verpakkingen kunnen via een gescheiden recyclingproces worden omgezet in food-grade gerecycled HDPE, wat bijvoorbeeld weer gebruikt kan worden om nieuwe melkcontainers mee te maken. Een vergelijkbaar systeem is in Engeland operationeel. Melkresten kunnen goed verwijderd worden tijdens het recyclingproces. Wel kunnen bedorven melkresten zorgen voor geuroverlast bij de inzamelapparaten als de melkcontainers niet goed zijn omgespoeld en afgesloten. Voor een eventuele introductie in Nederland is nog veel werk nodig. Er zal een recyclingbedrijf moeten komen dat dit materiaal op een voedselveilige manier verwerkt, de tijdelijke goedkeuring ${ }^{1}$ zal bij EFSA moeten worden aangevraagd en de inzamelapparaten moeten worden aangepast. Hierbij is de beperkte marktomvang van deze melk-containers een nadeel, maar misschien kan er met buitenlandse systemen worden samengewerkt om voldoende materiaal te krijgen zodat de gescheiden recycling zinvol wordt.

4. HDPE sap-containers (jugs). Dit is dezelfde verpakking als de melkcontainers, alleen is de inhoud anders en die laat meer productresten na en voegt Citrus-geurmoleculen toe aan het recyclaat. Daarmee wordt de kans groter dat het recyclingproces deze niet volledig kan verwijderen. Daarom heeft het momenteel geen voordeel om deze verpakking onder een statiegeldsysteem te brengen, tenzij de technische uitdagingen worden overwonnen en er een wasproces wordt ontwikkeld dat deze productresten en geuren in voldoende mate kan verwijderen. Mocht wel voor een statiegeld systeem gekozen worden, dan kunnen deze verpakkingen mogelijkerwijs worden omgezet in een food-grade rPE recyclaat. Het recyclingbedrijf zal dan wel een geschikt proces moeten ontwikkelen en een tijdelijke goedkeuring ${ }^{1}$ moeten aanvragen bij de EFSA .

5. Andere HDPE drankflessen. Dit zijn flessen voor gesteriliseerde melkproducten en kleine flesjes voor probiotica. Een deel van de HDPE flessen voor gesteriliseerde melkproducten heeft een zwarte binnenlaag om lichtschade aan het product te voorkomen. Er is geen recyclingproces bekend dat hieruit gerecycled PE kan maken dat geschikt is voor voedingsmiddelencontact. Deze flessen kunnen voorlopig het beste binnen het PMD systeem blijven en samen met andere PE verpakkingen worden verwerkt tot donkergrijs $r P E$, er is onzes inziens geen duidelijk voordeel om deze flessen met een statiegeldsysteem te gaan inzamelen.

6. PS Flesjes met Probiotica. De probiotica flesjes zijn klein. Deze flesjes zijn niet hersluitbaar en dit product is een dik viskeuze vloeistof die lastig af te wassen is. Er is geen duidelijk voordeel om dit aan het statiegeldsysteem toe te voegen.

7. PP drankflessen. Zover ons bekend worden er op dit moment PP flesjes voor dranken heel beperkt toegepast. Tot enkele jaren geleden waren er enkele fruitsappen in verpakt. Gelet op de geringe hoeveelheid loont het niet om hier een apart recyclingproces op te baseren en het toevoegen aan het statiegeldsysteem dus ook geen meerwaarde.

8. Glazen drankflessen. Een aantal luxe en/of biologische vruchtensappen, frisdranken en waters en lokaal gemaakte limonades worden verkocht in glazen flessen. Een gedeelte wordt verkocht via de supermarkten, een ander deel via boerderijwinkels en specialiteitsvoedingszaken. Deze grote glazen flessen passen niet makkelijk bij de formaten die nu voor bier gangbaar zijn, dus voor supermarkten zou het ongemakkelijk zijn om deze in te zamelen. In veel kleine boerderijwinkels, kleinschalige supermarktketens en specialiteitenzaken zou een statiegeldsysteem waarschijnlijk wel makkelijk in te voeren zijn en in sommige gevallen is er al ook al een statiegeldsysteem in gebruik met soms ook meermalig bruikbare flessen. Glas is verder goed te reinigen en opnieuw te vullen of te recyclen. De meerwaarde van het toevoegen van deze flessen aan een statiegeldsysteem voor het aandeel dat via de supermarkten wordt verkocht lijkt beperkt, terwijl dit voor het aandeel dat via de lokale kleine winkels wordt verkocht groter kan zijn. Het recyclingpercentage voor

\footnotetext{
${ }^{1}$ Formeel is dit een opinie van de EFSA die de proces-grondstof combinatie van het recyclingbedrijf als gunstig beoordeelt vooruitlopend op een toekomstige, definitieve autorisatie door de EC in het kader van EC 282/2008.
} 
statiegeldsysteem zou er in bestaan dat het recyclingpercentage tot boven de $90 \%$ stijgt en dat er met meermalig bruikbare (hervulbare) flessen kan worden gewerkt.

9. Glazen flessen voor wijn en gedestilleerde dranken. Wijnflessen worden op dit moment goed ingezameld via de brengbakken voor verpakkingsglas. Een eventuele invoering van een meermalig bruikbare wijnfles heeft weinig toegevoegde waarde omdat veel wijn wordt gebotteld in het land van oorsprong en die flessen dan ook weer terug getransporteerd zouden moeten worden. De glazen flessen die gebruikt worden voor de brede productgroep van gedestilleerde dranken en andere sterke dranken zijn bewust nog niet gestandaardiseerd in vorm, kleur en inhoudsmaat omdat deze ontwerpaspecten volgens producenten belangrijk zijn voor de verkoop van het product. Dit maakt de invoering van een statiegeldsysteem ingewikkeld, terwijl het potentiële voordeel gering lijkt.

10. Bierflessen die nu nog geen onderdeel vormen van het statiegeldsysteem. Dit zijn een beperkt aantal importflessen uit landen als bijvoorbeeld Mexico en China en flessen van kleine, lokale Nederlandse brouwers. Betrokkenen schatten het aandeel van niet-statiegeld-bierflessen in totaal op minder dan $10 \%$. Het eenvoudigweg toevoegen van deze bierflessen aan het statiegeldsysteem is onwenselijk en kan een goedwerkend systeem bemoeilijken. Immers deze flessen zijn vaak eenmalig bruikbaar en niet hervulbaar. Eerst zullen de nieuwe flessen moeten worden aangepast aan de eisen die gesteld worden aan hervulbare flessen voor wat betreft de vorm, het etiket en de lijm. Het loont voor kleine brouwers niet om apparatuur te kopen om de hervulbare flessen te reinigen en te controleren. Toch is het na gezamenlijk overleg met de andere brouwers wel mogelijk dat deze kleine brouwers aansluiten bij het statiegeldsysteem. Een mogelijke vorm zou kunnen zijn dat deze kleine brouwers nieuwe hervulbare flessen (bijvoorbeeld BNR of andere deelflessen) inzetten die dan door de grotere brouwers worden gereinigd en hervuld. Hiervoor moeten dan wel onderlinge afspraken worden gemaakt over bijvoorbeeld etiketgebruik, lijmgebruik en onderlinge vergoedingen.

11. Drankenkartons. Drankenkartons worden in Nederland gebruikt voor het verpakken van sap en zuivelproducten. Kenmerkend voor Nederland is dat een fors deel (ca. 40\%) van deze pakken zogenoemde 'dikke zuivelproducten' bevatten zoals yoghurt, vla en drinkyoghurt. In ons omliggende landen wordt yoghurt verkocht in beker- of potverpakkingen en/of bestaat het product vla überhaupt niet. Dit heeft als gevolg dat Nederlandse drankenkartons relatief veel productresten bevatten en bekend staan bij de recyclingbedrijven als sterk vervuild. Ze worden momenteel met het PMD gescheiden ingezameld of uit het huishoudelijk restafval nagescheiden en apart gesorteerd en gerecycled. Hieruit wordt pulp teruggewonnen waar golfkarton en kokers van gemaakt kunnen worden. Toevoegen aan het statiegeldsysteem heeft onzes inziens geen voordeel. De vorm van de openingen van de machines zou moeten worden aangepast. Consumenten zal moeten worden uitgelegd dat ze hun pakken moeten uitspoelen en plat maken, en dat lijkt niet realistisch. De inzamelmachines zullen vaker moeten worden gereinigd en de drankenkartons zullen uiteindelijk bij dezelfde recyclingbedrijven terechtkomen.

12. Pouches. Drankzakjes zijn ontwikkeld om het materiaalgebruik per verpakking te minimaliseren. Ze kunnen niet gerecycled worden, daarom is er wat betreft recyclebaarheid ook geen meerwaarde om ze aan het statiegeldsysteem toe te voegen. Eventuele meerwaarde zou een reductie van het zwerfafval kunnen zijn, al is de vraag of dat in de praktijk ook zo uitpakt. 
Tabel 2 Beknopt overzicht van de voor en nadelen van het opnemen in een statiegeldsysteem van verschillende drankverpakkingen.

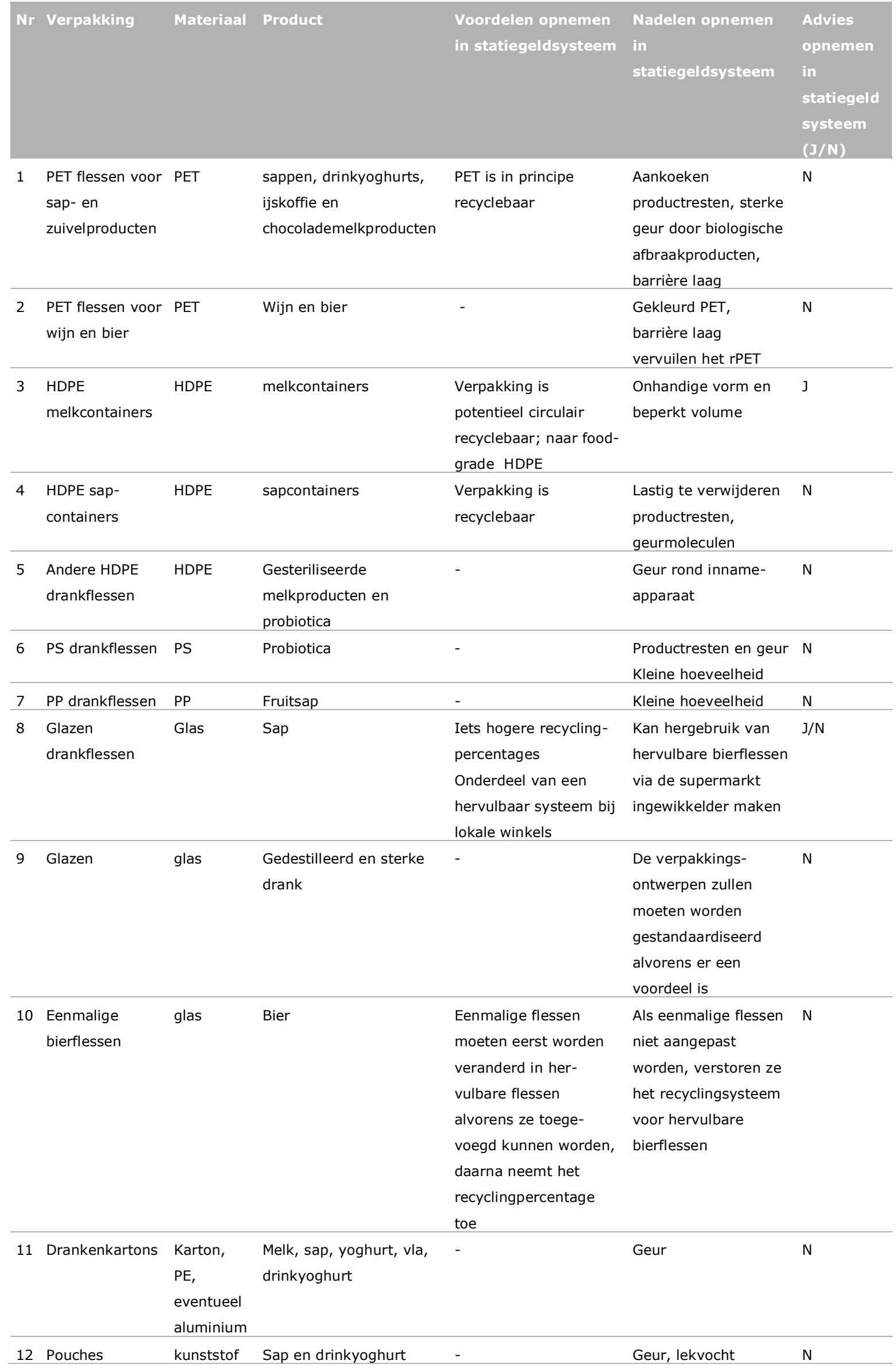




\section{Algemene noot ter afsluiting}

Voor alle betrokkenen in de verkoop van levensmiddelen, de verwerking van ons afval en de recycling van onze secundaire grondstoffen geldt dat ze consistentie van overheidsbeleid willen. De betrokkenen moeten grote veranderingen doorvoeren in hun operationele activiteiten bij elke beleidswijziging die verschuivingen in de materiaalstromen te weeg brengt. Daarom is het wenselijk dat de overheid zijn ingrepen in de markt zoveel mogelijk gelijktijdig laat plaatsvinden en dit ook verricht vanuit een lange termijns-toekomstvisie.

Daarnaast zou het - in het algemeen - helpen wanneer producenten meer uniforme verpakkingen op de markt zetten, zodat meer verpakkingen in de toekomst in aanmerking komen voor een statiegeldsysteem.

Zoals in de inleiding vermeld staat, is dit document geschreven op basis van beschikbare kennis en ervaring. Wanneer er meer gedetailleerde informatie gewenst is op dit onderwerp, is een uitgebreider onderzoek nodig. 


\section{Verwijzingen}

Brouwer, M. T., Thoden van Velzen, E. U., Augustinus, A., Soethoudt, H., De Meester, S., \& Ragaert, K. (2018). Predictive model for the Dutch post-consumer plastic packaging recycling system and implications for the circular economy. Waste Management, 71, 62-85. https://doi.org/10.1016/j.wasman.2017.10.034

Brouwer, M., Picuno, C., Thoden van Velzen, E. U., Kuchta, K., De Meester, S., \& Ragaert, K. (2019). The impact of collection portfolio expansion on key performance indicators of the Dutch recycling system for Post-Consumer Plastic Packaging Waste, a comparison between 2014 and 2017. Waste Management, 100, 112-121. https://doi.org/10.1016/j.wasman.2019.09.012

Brouwer, M., Thoden van Velzen, U., \& Workala, Y. (2021). Recyclebaarheid van Nederlandse kunststofverpakkingen : de status van 2021. (Rapport / Wageningen Food \& Biobased Research; No. 2150). Wageningen Food \& Biobased Research. https://doi.org/10.18174/546479

Picuno, C., van Eygen, E., Brouwer, M., Kuchta, K., \& Thoden van Velzen, E. U. (2021). Factors Shaping the Recycling Systems for Plastic Packaging Waste-A Comparison between Austria, Germany and The Netherlands. Sustainability (Switzerland), 13(12), [6772]. https://doi.org/10.3390/su13126772

Thoden van Velzen, E. U., Huremović, D., Keijsers, E. R. P., op den Kamp, R., \& Brouwer, M. T. (2017). Recycling of beverage cartons in the Netherlands 2016: technical report. (Wageningen Food \& Biobased Research report; No. 1781). Wageningen Food \& Biobased Research. https://doi.org/10.18174/427248

Zhou, G., Gu, Y., Wu, Y., Gong, Y., Mu, X., Han, H., Chang, T. (2020). A systematic review of the deposit-refund system for beverage packaging: Operating mode, key parameter and development trend. Journal of Cleaner Production 251, 119660. https://doi.org/10.1016/j.jclepro.2019.119660 



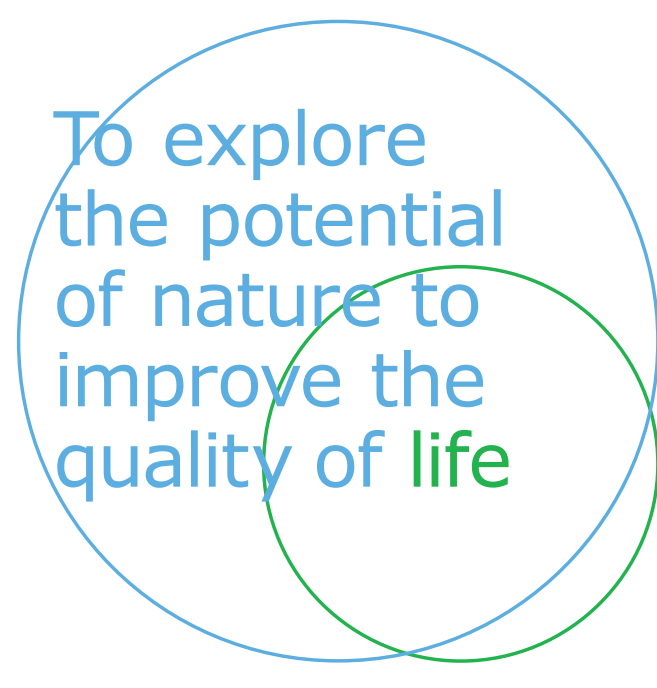

Wageningen Food \& Biobased Research Bornse Weilanden 9

\section{WG Wageningen}

www.wur.nl/wfbr

info.wfbr@wur.nl

Rapport 2166

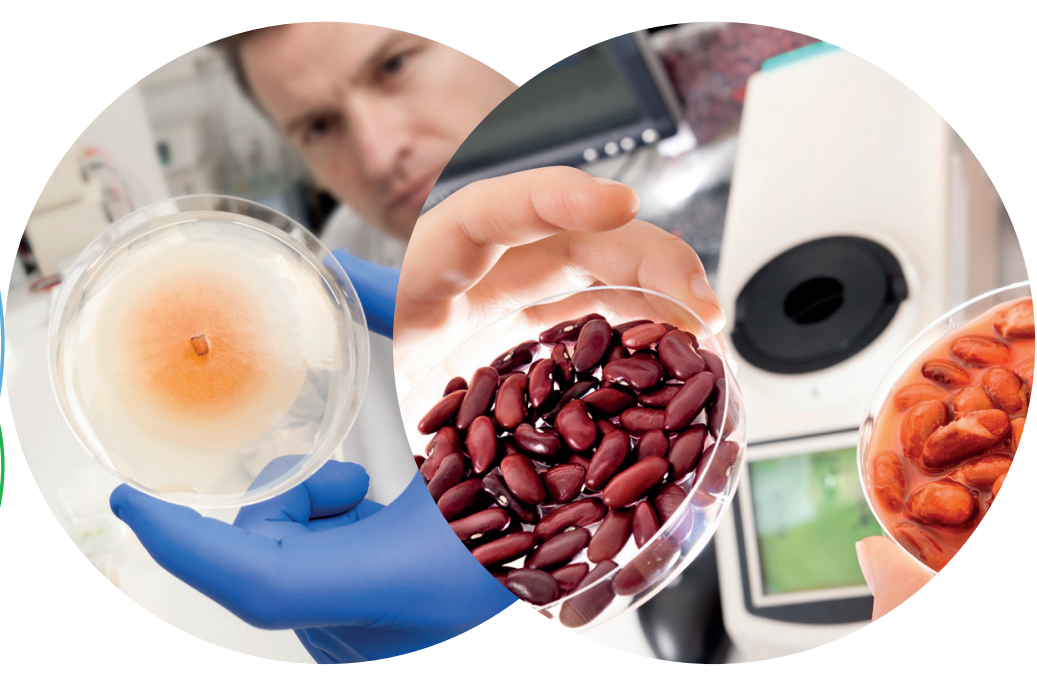

De missie van Wageningen University \& Research is 'To explore the potential of nature to improve the quality of life'. Binnen Wageningen University \& Research bundelen Wageningen University en gespecialiseerde onderzoeksinstituten van Stichting Wageningen Research hun krachten om bij te dragen aan de oplossing van belangrijke vragen in het domein van gezonde voeding en leefomgeving. Met ongeveer 30 vestigingen, 6.800 medewerkers (6.000 fte) en 12.900 studenten behoort Wageningen University \& Research wereldwijd tot de aansprekende kennisinstellingen binnen haar domein. De integrale benadering van de vraagstukken en de samenwerking tussen verschillende disciplines vormen het hart van de unieke Wageningen aanpak. 